\title{
Predisposing factors to protein energy malnutrition among children (0-5years) in umuogele umuariam community in obowo local government area of Imo state, Nigeria
}

\begin{abstract}
This non-experimental, cross-sectional descriptive study assessed the "predisposing factors to protein energy malnutrition among children in Umuogele Umuariam Community, in Obowo Local Government Area of Imo State." The target population comprised all the mothers in Umuogele Umuariam Community, in Obowo Local Government Area who has children (0-5years). The sample size consisted of 150 respondents who were selected using the convenient sampling technique after stratified sampling method. Data was collected from the mothers through self-structured and validated questionnaires. Data collected were presented in frequency and percentage. Mean scores were used to analyze the data. 2.50 was chosen as the bench mark ( $\geq 2.5$ as criteria of acceptance). Inferential statistics (chi-square) (x2) was used to test the hypothesis at 0.05 level of significance. Findings revealed that the mothers do not have very good knowledge of protein-energy malnutrition, that ignorance on food nutrition, non-practice of exclusive breastfeeding and poor weaning methods were the major factors that predispose children to protein energy malnutrition. Result also shows that proper nutrition, exclusive breastfeeding and proper weaning can be an effective tool in reducing PEM among under five children. Based on the results, the researchers recommended that enhancement in both knowledge and practice is greatly required on the following areas of exclusive breast milk, initiation of breast milk, continuous feeding of breast milk and good dietary practices.
\end{abstract}

Keywords: predisposing, factors, protein-energy malnutrition, children
Volume 6 Issue 4 - 2017

\author{
Emmanuel O Chukwu,' Terna M Fiase,' Habu \\ Haruna, ${ }^{2}$ Dathini Hamina, ${ }^{2}$ Kever T Robert, ${ }^{2}$ \\ Esther $\mathrm{M}$ lornengen ${ }^{3}$ \\ 'School of Nursing Mkar, Gboko, Nigeria \\ ${ }^{2}$ Department of Nursing Science, University of Maiduguri, \\ Nigeria \\ ${ }^{3}$ School of Midwifery Mkar, Gboko, Nigeria
}

Correspondence: Emmanuel O Chukwu, School of Nursing Mkar, P.M.B. 19 Gboko, Benue State, Nigeria, Tel +2348065909485, Email emmanwaguy42@yahoo.com

Received: May 04, 2017 | Published: May 12, 2017

\section{Introduction}

Nutrition is one of the cornerstones of maintaining health and preventing illness. According to Basavanthappa (2011), nutrition is the sum of all the interactions between an organism and the food it consumes. In other words, nutrition is what a person eats and how the body uses it. Nutrition is an essential principle which must be applied throughout the life cycle. Periods of nutrition emphases include during pregnancy, infancy, childhood, adolescence, adulthood and the "older" adult. The relationship between diet and health is strong. Protein energy malnutrition (PEM) is the term given to a group of clinical conditions which occur due to inadequate protein and calorie intake, especially in children. Protein energy malnutrition is a grave problem in developing countries as pregnant mothers do not eat enough nutrition and healthy food, which puts the baby at a disadvantage even before he/she is born. PEM has been classified in many ways, two important types are; Kwashiorkor and, Marasmus.

\section{Kwashiorkor}

Is a form of malnutrition most often found in children. It is caused by not eating enough protein, despite a reasonable intake of calories. It is common in areas of drought and famine. Symptoms may include irritability and fatigue followed by slowed growth, weight loss and muscle wasting, generalized swelling, skin change, enlargement of liver and abdomen and weakening of the immune system, leading to frequent infection. ${ }^{1}$ Children are affected by kwashiorkor more frequently than adults. It typically starts after the child has been weaned and breast milk has been replaced with a diet low in protein, although it can occur in infant if the mother is protein deprive. ${ }^{2}$ Kwashiorkor can also occur due to parasite and infections that can interfere with nutritional status. Left untreated, kwashiorkor can cause life threatening shock and coma. Treatment of kwashiorkor depends upon its severity. Fluid and electrolyte imbalances may need to be corrected with intravenous fluids, and infections may require treatment with antibiotics.

\section{Marasmus}

Is a severe form of malnutrition that consists of the chronic wasting away of fat, muscle, and other tissues in the body. Marasmus symptoms will vary depending on the severity and whether associated infections or other conditions are present. General symptoms of marasmus include chronic diarrhea, dizziness, fatigue and rapid weight loss. Marasmus is caused by inadequate amount of both protein and calories that are consumed, resulting in an energy deficit in the body. Treatment is based on nutritious, well balanced diet with lots of fresh fruits and vegetables, grains and protein. ${ }^{3,4}$ 


\section{Causes of protein energy malnutrition}

The primary type of PEM is purely due to dietary deficiency. This begins at the fetal stage and continues into infancy and childhood. Nearly $25 \%$ of the pediatric hospital beds in India are occupied by children suffering from malnutrition and around $80 \%$ of hospitalized children are malnourished to some extent, hence this contributes to the infant mortality ratio in a big way. ${ }^{5}$ Secondary malnutrition arises due to a serious illness like tuberculosis, cancer or inability of the body to absorb nutrients. For example in bowed disease like ulcerative colitis, metabolic syndromes and long standing gastroenteritis. Dietary factors contributing to PEM are inadequate breast feeding by the mother due to inability of mother's body to make milk due to inadequate nutrition, ignorance of weaning and weaning foods, inverted or cracked nipples in mother causing difficulty in breast feeding. ${ }^{6,7}$

The incidence of protein energy malnutrition in children have been the subject of extensive research for several decades, and studies shows that protein energy malnutrition affects the growth and development of children especially (0-5years). A well nourish child is one with access to adequate food supply, care and health, such a child will have weight and height measurements that compare very well with the standard normal distribution of height $(\mathrm{H})$ and weight $(\mathrm{W})$ of healthy children of the same age and sex. The best way to evaluate the nutritional status and overall health of a child is to compare the child's growth indices with the set cult off points in the standard normal distribution of well-nourished children that are associated with adequate growth and development. ${ }^{8-10}$

A healthy diet provides an adequate supply of all the nutrients that is necessary for best functioning of body cells;

i. Water as a transport medium of all chemical processes

ii. Protein for tissue repair, maintenance and growth

iii. Carbohydrate for energy given

iv. Fat for insulation, nerve conductivity and hormones structure

v. Vitamins and mineral for regulation on body physiological processes. $^{11}$

Throughout the world, approximately $9 \%$ of children from below fiveyears of age are suffering from wasting, stunting and are at risk of several impairment in growth, psychological development and health. ${ }^{12}$ In Nigeria, incidence of PEM records stunting among children below fiveyears is $41 \%$, wasting among children below fiveyears $14 \%$, underweight approximately $23 \%$ severe underweight cases $-32.6 \%$ stunting rate. ${ }^{13}$ World Health Organization (WHO) estimated that by the year 2014, the prevalence of protein energy malnutrition will have decreased to $17.6 \%$ globally. The prevalence of protein energy malnutrition rate has continued to rise in Africa and have risen from $24 \%$ to $26 \%$ and $47.3 \%$ to $45 \%$ respectively, since $1990-2010$ with the worst increase occurring in the region of Africa. ${ }^{14}$

\section{Objectives of the study}

i. To determine the level of knowledge of mothers in Umuariam community on protein energy malnutrition.

ii. To assess the predisposing factors to PEM in Umuariam community in Obowo L.G.A of Imo State. iii. To determine possible preventive measures of Protein energy Malnutrition (PEM) in the community

\section{Study hypotheses}

i. Mothers have no knowledge on protein energy malnutrition

ii. There are no predisposing factors to protein energy malnutrition

iii. There are no possible preventive measures to protein energy malnutrition

\section{Research method \\ Design of Study}

Cross-sectional descriptive survey method was used for this study to determine the incidence and treatment outcome of protein energy malnutrition among children in Umuogele Umuariam community in Obowo local government area of Imo state.

\section{Target population}

The target population consists of mothers in Umuariam Community in Obowo L.G.A of Imo State. Umuariam communities have about 260 estimated mothers having children 0-5.

\section{Determination of Sample Size}

Using the formula

$$
n=\frac{N}{1+N e^{2}}
$$

Where

$$
\begin{aligned}
& \mathrm{n}=\text { sample size sought } \\
& \mathrm{N}=\text { population size } \\
& \mathrm{e}=\text { Level of significance chosen } \\
& 1=\text { Constant }
\end{aligned}
$$

Level of significance chosen is $5 \%(0.05)$

Therefore,

$$
\begin{gathered}
n=\frac{260}{1+2600(0.05)^{2}} \\
=157.57 \\
=157.57
\end{gathered}
$$

Therefore, the sample size $=158$

\section{Sample/sampling technique}

The researcher selected 31 mothers from each of the 5 villages in Umuariam community to make a total of 158 sample size using simple random sampling method. In order to pick respondents for the research, the mothers in each village were gathered in the village square and the ballot method without replacement was used. Here, "Yes" and "No" were written on papers and the papers were folded, then every member of the sample unit (mothers) was given equal opportunity to pick from the papers. Then, only those who picked the ones with "Yes" and obliged to participate in the study were selected 
as sample whereas those that picked the ones with "No" and those who picked "yes" but were not obliged to participate in the study were not selected as sample.

\section{Instrument for data collection}

A self-designed, structured questionnaire was used for data collection. The questionnaire was designed in line with the objective of the study. It has sections, with each section eliciting information on the research question.

The questionnaire has first introductory part, where the researcher introduces himself to his respondents, instructing them on what is expected of them and how to answer the questions. Section "A" of the questionnaire has to do with the socio-demographic data of the respondents. Section "B" was designed to initiate information on the research questions number one and correspondingly Section " $\mathrm{C}$ " and "D" taking care of research question 2 and 3 .

\section{Method for data collection}

158 questionnaires was distributed by the researchers to all the mothers who were selected from the five villages in Umuariam community using simple random sampling method, making use of ballot paper method as described under sample and sampling techniques above. The questionnaires were given to the respondents at the village square and respondents who could not fill theirs immediately took it home and were given opportunity to return it to a predetermined office where the researchers went to retrieve them on the second day.

\section{Method of data analysis}

The demographic data obtained from the distributed questionnaires were analyzed and presented using frequency distribution table while mean scores were used to analyze the remaining data and interpreted as from which $>2.50$ as positive and $<2.50$ as negative. Chi-square (X2) was used to test the hypotheses at 0.05 level of significance.

\section{Data analysis and presentation of result}

The questionnaire distributed was 158 while 156 was returned out of which 150 was completely filled. The results are hereby presented in frequency distribution table according to research questions.

\section{Marital status}

The above table data reveals that out of 150 respondents, $20(13 \%)$ were single, $90(60 \%)$ were married, $10(7 \%)$ were divorced, while 30 $(20 \%)$ were widowed. This implies that majority of the respondents were married women.

\section{Occupation}

Data in the table above reveals that out of 150 respondents, 70 $(47 \%)$ were civil servants, $30(20 \%)$ were traders, $20(13 \%)$ were house wife, while $30(20 \%)$ were farmers.

Religion: Table 1 information above reveals that out of 150 respondents, 140 (93\%) were Christians, 10 (7\%) were Islam, whereas none of the respondents were Moslem and other this implies that $90 \%$ of respondents were Christians.

\section{Educational status}

Data in Table 1 above reveals that out of 150 respondents, 20 $(13 \%)$ completed primary school, $40(27 \%)$ secondary school, 60
$(40 \%)$ tertiary school, while $30(20 \%)$ did not have formal education, this implies that the highest educational attainment of majority of respondents was tertiary school.

Table I Demographic data of respondents $\mathrm{N}=150$

\begin{tabular}{|c|c|c|}
\hline Marital status & Frequency & Percentage (\%) \\
\hline Single & 20 & 13 \\
\hline Married & 90 & 60 \\
\hline Divorced & 10 & 7 \\
\hline Widowed & 30 & 20 \\
\hline Total & 150 & 100 \\
\hline Educational Qualification & Frequency & Percentage (\%) \\
\hline Primary & 20 & 13 \\
\hline Secondary & 40 & 27 \\
\hline Tertiary & 60 & 40 \\
\hline No formal education & 30 & 20 \\
\hline Total & 150 & 100 \\
\hline Occupation & Frequency & Percentage (\%) \\
\hline Civil Servant & 70 & 47 \\
\hline Trading & 30 & 20 \\
\hline House Wife & 20 & 13 \\
\hline Farming & 30 & 20 \\
\hline Total & 150 & 100 \\
\hline Religion & Frequency & Percentage (\%) \\
\hline Christianity & 140 & 93 \\
\hline Islam & 10 & 7 \\
\hline Pagan & - & - \\
\hline Others & - & - \\
\hline Total & 150 & 100 \\
\hline Number of Children & Frequency & Percentage (\%) \\
\hline I-3 Children & 90 & 60 \\
\hline 3-6 Children & 30 & 20 \\
\hline 7 and Above & 30 & 20 \\
\hline Total & 150 & 100 \\
\hline
\end{tabular}




\section{Number of children}

The Table 1 above shows that $90(60 \%)$ of the respondents have Children ranging from 1-3 Children, $30(20 \%)$ of them have 3-6 Children, while $30(20 \%)$ have 7 Children and above.

Note $:<2.50$ means negative, $>2.50$ means positive

Table 2 Level of knowledge of the mothers on PEM $N=150$
From Table 2 above, some of the items in the table have mean scores above 2.50 and some below. The cluster mean of 2.50 shows that the mothers do not have very good knowledge of protein-energy malnutrition.

Note $:<2.50$ means negative, $>2.50$ means positive

\begin{tabular}{|c|c|c|c|c|c|c|c|}
\hline S. no & Items & SA & A & $\mathbf{D}$ & SD & Mean & Remark \\
\hline I & MOTHER have heard about protein energy malnutrition & 27 & 33 & 44 & 46 & 2.27 & \\
\hline 2 & Mothers have seen children suffered from PEM & 38 & 59 & 27 & 26 & 2.73 & \\
\hline 3 & Mother have not experienced their children been sick & 14 & 27 & 53 & 56 & 1.99 & \\
\hline 4 & $\begin{array}{l}\text { Your children have been recommended to eat vegetable and } \\
\text { beans }\end{array}$ & 47 & 69 & 26 & 9 & 3.02 & \\
\hline & Cluster Mean & & & & & 2.5 & \\
\hline
\end{tabular}

From Table 3 above, all the items in the table have mean scores above 2.50. The cluster mean of 3.55 shows that ignorance on food nutrition, non-practice of exclusive breastfeeding and poor weaning methods were the major factors that predispose children to protein energy malnutrition.

Note $:<2.50$ means negative, $>2.50$ means positive

Table 3 Predisposing factors to PEM N=150

\begin{tabular}{|c|c|c|c|c|c|c|c|}
\hline S.no & Items & SA & A & D & SD & Mean & Remark \\
\hline I & The most available food crop in your are is rich and yam & 63 & 57 & 17 & 13 & 3.13 & \\
\hline 2 & There is vegetable in your area & 6 & 11 & 96 & 33 & 1.5 & \\
\hline 3 & You give children eggs to eat & 9 & 15 & 39 & 87 & 1.64 & \\
\hline 4 & Food taboo forbid eggs and other meat in your area & 43 & 81 & 22 & 4 & 3.09 & \\
\hline 5 & You know protein given food items & 3 & 9 & 107 & 31 & 1.89 & \\
\hline 6 & You practice exclusive breast feeding & 26 & 39 & 67 & 18 & 2.49 & \\
\hline 7 & $\begin{array}{l}\text { Pap is the most common food to introduce to children after breast } \\
\text { feeding }\end{array}$ & 87 & 32 & 27 & 4 & 3.15 & \\
\hline & Cluster Mean & & & & & 2.47 & \\
\hline
\end{tabular}


From Table 4 above, all the items in the table have mean scores above 2.50 . The cluster mean of 3.24 shows that the respondents agreed that preventive factors to PEM are multifactorial which borders mainly on education of mothers on food nutrition.

Table 4 Preventive measures of PEM $N=150$

\begin{tabular}{|c|c|c|c|c|c|c|c|}
\hline S. no & Items & SA & A & D & SD & Mean & Remark \\
\hline I & Nursing mothers need lectures on child malnutrition & 68 & 74 & 5 & 3 & 3.38 & \\
\hline 2 & Nursing mother need knowledge on food contents of food items & 67 & 78 & 4 & 1 & 3.48 & \\
\hline 3 & $\begin{array}{l}\text { Mothers need knowledge on the kinds of food to be given to children } \\
\text { at each age and stage of development }\end{array}$ & 68 & 78 & 4 & 0 & 3.43 & \\
\hline 4 & You are aware of food items and their respective classes (content) & 4 & 8 & 103 & 30 & 1.91 & \\
\hline 5 & You are aware that a child can be malnourished & 98 & 47 & 5 & 0 & 3.62 & \\
\hline 6 & $\begin{array}{l}\text { lack of knowledge on food items with their contents can result to } \\
\text { malnutrition }\end{array}$ & 64 & 69 & 17 & 0 & 3.31 & \\
\hline 7 & Poverty contribute to malnutrition & 73 & 57 & 20 & 0 & 3.35 & \\
\hline 8 & Women would like knowledge on balanced diet & 73 & 61 & 12 & 4 & 3.35 & \\
\hline 9 & $\begin{array}{l}\text { Women would like to cultivate crops that will make them have a } \\
\text { balanced diet }\end{array}$ & 75 & 62 & II & 2 & 3.4 & \\
\hline & Cluster Mean & & & & & 3.24 & \\
\hline
\end{tabular}

\section{Testing of hypotheses}

\section{Hypothesis I: Mothers have no knowledge on protein energy malnutrition}

The calculated $\mathrm{X}^{2}=1471.67$

The tabulated $\mathrm{X}^{2}=16.92$

Since the Chi-square $\left(\mathrm{X}^{2}\right)$ test (calculated) $=1471.67$ is greater than the tabulated value $=16.92$ There is therefore no statistical evidence to accept the null hypothesis (Ho). This means that the mothers have some degree of knowledge on PEM.

Hypothesis 2: There are no predisposing factors to protein energy malnutrition

The calculated $\mathrm{X}^{2}=14483.08$

The tabulated $\mathrm{X}^{2}=28.87$

Since the Chi-square $\left(\mathrm{X}^{2}\right)$ test (calculated) $=14483.08$ is greater than the tabulated value $=28.87$. There is therefore no statistical evidence to accept the null hypothesis (Ho). This means that there are factors predisposing to PEM.

\section{Hypothesis 3: There are no possible preventive measures to protein energy malnutrition}

The calculated $\mathrm{X}^{2}=2664.9$

The tabulated $\mathrm{X}^{2}=36.42$

Since the Chi-square $\left(X^{2}\right)$ test (calculated) $=2664.9$ is greater than the tabulated value $=36.42$ There is therefore no statistical evidence to accept the null hypothesis (Ho). This means that there are preventive measures to PEM.(Table 5), (Table 6), (Table 7).
Table 5 Chi-square $\left(\mathrm{X}^{2}\right)$ test on level of knowledge of mothers on PEM

\begin{tabular}{|c|c|c|c|c|}
\hline 0 & $\mathbf{E}$ & $(E-O)$ & $(E-O) 2$ & $(E-O) 2 / E=X^{2}$ \\
\hline 27 & 31.5 & -4.5 & 20.25 & 0.64 \\
\hline 33 & 8.3 & 24.7 & 610.09 & 73.5 \\
\hline 44 & 11 & 33 & 1089 & 99 \\
\hline 46 & 11.5 & 34.5 & 1190.25 & 103.5 \\
\hline 38 & 31.5 & 6.5 & 42.25 & 1.23 \\
\hline 59 & 8.3 & 50.7 & 2570.49 & 309.7 \\
\hline 27 & 11 & 16 & 256 & 23.27 \\
\hline 26 & 11.5 & 14,5 & 210.25 & 18.28 \\
\hline 14 & 31.5 & -17.5 & 306.25 & 9.72 \\
\hline 27 & 8.3 & 18.7 & 349.69 & 42.13 \\
\hline 53 & 11 & 42 & 1764 & 160.36 \\
\hline 56 & 11.5 & 44.5 & 1980.25 & 172.2 \\
\hline 47 & 31.5 & 15.5 & 240.25 & 7.63 \\
\hline 68 & 8.3 & 59.7 & 3564.09 & 429.41 \\
\hline 26 & 11 & 15 & 225 & 20.45 \\
\hline 9 & 11.5 & -2.5 & 6.25 & 0.55 \\
\hline Total & $147 \mid .67$ & & & \\
\hline
\end{tabular}


Table 6 Chi-square $\left(\mathrm{X}^{2}\right)$ test on predisposing factors to PEM

\begin{tabular}{|c|c|c|c|c|}
\hline 0 & $\mathbf{E}$ & $(E-O)$ & $(E-O) 2$ & $(E-O) 2 / E=X^{2}$ \\
\hline 63 & 9 & 54 & 2916 & 324 \\
\hline 57 & 8.1 & 48.9 & 2391.21 & 295.21 \\
\hline 17 & 2.4 & 14.6 & 213.16 & 88.82 \\
\hline 13 & 1.9 & II.I & $|23.2|$ & 64.85 \\
\hline 10 & 9 & I & I & 0.11 \\
\hline 96 & 2.4 & 93.6 & 8760.96 & 3650.4 \\
\hline 33 & 1.9 & 31.1 & 967.31 & 509.06 \\
\hline 9 & 9 & 0 & 0 & 0 \\
\hline 15 & 8.1 & 6.9 & 47.61 & 5.88 \\
\hline 39 & 2.4 & 36.6 & 1339.56 & 558.15 \\
\hline 87 & 1.9 & 85.1 & $7 \mid 42.01$ & 3811.58 \\
\hline 43 & 9 & 34 & 1156 & 128.44 \\
\hline 81 & 8.1 & 72.9 & $53|4.4|$ & 656.1 \\
\hline 22 & 2.4 & 199.6 & 384.16 & 160.07 \\
\hline 4 & 1.9 & 2.1 & 4.41 & 2.32 \\
\hline 3 & 9 & -6 & 36 & 4 \\
\hline 9 & 8.1 & 0.9 & 0.81 & 0.1 \\
\hline 107 & 2.4 & 104.6 & 10941.16 & 4558.82 \\
\hline 31 & 1.9 & 29.1 & 846.81 & 445.69 \\
\hline 26 & 9 & 17 & 289 & 32.11 \\
\hline 39 & 8.1 & 30.9 & 954.81 & 117.88 \\
\hline 67 & 2.4 & 64.6 & 4173.16 & 1738.82 \\
\hline 18 & 1.9 & 16.1 & 259.21 & 136.43 \\
\hline 87 & 9 & 78 & 6084 & 676 \\
\hline 32 & 8.1 & 23.9 & 571.21 & 70.52 \\
\hline 27 & 2.4 & 24.6 & 605.16 & 252.15 \\
\hline 4 & 1.9 & 2.1 & 4.41 & 2.32 \\
\hline Total & & & & 14483.08 \\
\hline
\end{tabular}

Table 7 Chi-square $\left(\mathrm{X}^{2}\right)$ test on preventive measures of PEM

\begin{tabular}{|c|c|c|c|c|}
\hline O & $\mathbf{E}$ & (E-O) & $(E-O) 2$ & $(E-O) 2 / E=X^{2}$ \\
\hline 68 & 63.1 & 4.9 & 24.01 & 0.3 \\
\hline 74 & 58.1 & 15.9 & 252.81 & 4.35 \\
\hline 5 & 8.4 & -3.4 & 11.56 & 1.38 \\
\hline 3 & 4.9 & -1.9 & 3.61 & 0.74 \\
\hline 67 & 63.1 & 3.9 & 15.21 & 0.24 \\
\hline 78 & 58.1 & 19.9 & 396.01 & 6.81 \\
\hline 4 & 8.4 & -4.4 & 19.36 & 2.3 \\
\hline I & 4.9 & -3.9 & 15.21 & 3.1 \\
\hline 68 & 63.1 & 4.9 & 24.01 & 0.38 \\
\hline 78 & 58.1 & 19.9 & 396.01 & 6.82 \\
\hline 4 & 8.4 & -4.4 & 19.36 & 2.3 \\
\hline 0 & 4.9 & -1.9 & 24.01 & 4.9 \\
\hline 4 & 63.1 & -59.1 & 2492.81 & 55.35 \\
\hline 8 & 58.1 & 150.1 & 2510.01 & 43.21 \\
\hline 108 & 8.4 & 99.6 & 9920.16 & 1180.97 \\
\hline 30 & 4.9 & 25.1 & 6300.1 & 1285.73 \\
\hline 98 & 63.1 & 34.9 & $|2| 8.0 \mid$ & 19.3 \\
\hline 47 & 58.1 & -11.1 & 123.21 & 2.12 \\
\hline 5 & 8.4 & -3.8 & 11.56 & 1.38 \\
\hline 0 & 4.9 & -4.9 & 24.01 & 4.9 \\
\hline 64 & 63.1 & 0.9 & 0.81 & 0.01 \\
\hline 69 & 58.1 & 10.1 & || $8.8 \mid$ & 2.04 \\
\hline 17 & 8.4 & 8.6 & 73.96 & 8.8 \\
\hline 0 & 4.9 & -4.9 & 24.01 & 4.9 \\
\hline 73 & 63.1 & 9.9 & 98.01 & 1.55 \\
\hline 57 & 58.1 & -1.1 & 1.21 & 0.02 \\
\hline 20 & 8.4 & 11.6 & 134.56 & 16.02 \\
\hline 0 & 4.9 & -4.9 & 24.01 & 4.9 \\
\hline Total & & & & 2664.9 \\
\hline
\end{tabular}




\section{Discussion of findings}

\section{Level of knowledge of mothers in umuariam community on protein energy malnutrition}

From Table 2 above, some of the items in the table have mean scores above 2.50 and some below. The cluster mean of 2.50 shows that the mothers do not have very good knowledge of protein-energy malnutrition. This finding is in agreement with ${ }^{6}$ whose study on "Assessment of Knowledge of Mothers of Under five Children on Nutritional Problems: A Rural Community Based Study" showed that of the mothers surveyed, knowledge about under five nutritional problems and its prevention was reported to be nearly half of the mothers 27 (54\%) had poor knowledge, around $19(38 \%)$ had average knowledge, and only $4(8 \%)$ had good knowledge regarding the common nutritional problems and its prevention. Mothers had poor knowledge on under five nutritional problems and its prevention. None of the mothers had very good knowledge. A significant number of mothers were unaware of the prevention and management of under five nutritional problems. The finding of the study is also supported by ${ }^{13}$ whose study showed that $42 \%$ of mothers been surveyed had an average level of knowledge about Protein Energy Malnutrition (PEM), $37 \%$ and $10 \%$ of them had poor and very poor level of knowledge and $11 \%$ of the mothers had good knowledge regarding PEM. The finding is also in agreement with ${ }^{14,15}$ who stated that ignorance of mothers about protein energy malnutrition is one of the causes of PEM among children of $0-5$ years especially in developing countries. The implication of this finding is that frequent health education campaigns should be conducted in the field of child nutrition among the mothers.

\section{Predisposing factors to protein energy malnutrition in Umuariam community in Obowo L.G.A of Imo State}

From Table 3 above, all the items in the table have mean scores above 2.50. The cluster mean of 3.55 shows that ignorance on food nutrition, non-practice of exclusive breastfeeding and poor weaning methods were the major factors that predispose children to protein energy malnutrition. This findings agrees with [11] whose study showed that PEM was more common among children from the lower social class $(69.4 \%)$ and those predominantly breast fed for three months or less $(48.6 \%)$ compared to exclusively breast fed children $(18.9 \%)$. The reason for this may not be unconnected to the fact that poor families have low purchasing power for adequate nutritious foods for their families. Illiteracy on the other hand, may influence feeding practices. This finding also agrees with ${ }^{16,17}$ which holds that lack of breastfeeding can lead to protein energy malnutrition in infant and children. Possible reasons for this in the developing world may be that the average family thinks that bottle feeding is better. ${ }^{18}$ Also holds that mothers abandon breastfeeding because they do not know how to get their baby position properly or to suffer pain and discomfort during breastfeeding. The above finding also agrees with the finding of ${ }^{11}$ which showed that poor weaning of children is one of the predisposing factors to protein energy malnutrition. The implication of this finding is that enhancement in both knowledge and practice is greatly required on the following areas of exclusive breast milk, initiation of breast milk, continuous feeding of breast milk and good dietary practices.

\section{Possible preventive measures of protein energy malnutrition among under fiveyears children in Obowo L.G.A of Imo State}

From Table 4 above, all the items in the table have mean scores above 2.50 . The cluster mean of 3.24 shows that the respondents agreed that preventive factors to PEM are multifactorial which borders mainly on education of mothers on food nutrition.

This means that exclusive breastfeeding and the combination of all the six classes of food are the preventive measures of occurrence of protein energy malnutrition in under five children. The above finding agrees with the finding of, ${ }^{19}$ which states that exclusive breastfeeding for at least six months is considered the best way to prevent early childhood protein energy malnutrition. This finding also agrees with ${ }^{20}$ which holds that lack of breastfeeding can lead to protein energy malnutrition in infant and children. Study by Nahar B et al. ${ }^{21}$ also showed that proper nutrition can be an important way of reducing PEM among under five children. This means that exclusive breastfeeding can be an effective tool in reducing PEM among young children.

\section{Implication for nursing}

The nursing implication to this article is to improve health and quantity of life through prevention of protein energy malnutrition in their children ( $0-5$ years). This can be implemental by health educating the community, especially mothers on the importance of exclusive breastfeeding and proper weaning, to discourage the community against food taboos and also educate mothers on how to prepare readily available food resources.

\section{Summary}

The purpose of this research work is to determine the predisposing factors to protein energy malnutrition among children (0-5) in Umuariam Community in Obowo L.G.A of Imo State.

The objectives of the study are: To determine the level of knowledge of mothers in Obowo community on Protein Energy malnutrition, to identify the predisposing factors to protein energy malnutrition in the community, to determine the preventive measure of protein energy malnutrition in the community. Literature review was carried out in chapter two to review different opinions of other authors about protein energy malnutrition. Research method used was systematic and simple random sampling technique and data was collected using questionnaires. The data were analyzed using the following statistical tools: figure (bar chart and histograms) and tables. The results were then discussed. The findings revealed that ignorance, food taboo, non-practice of exclusive breastfeeding and poor weaning by mothers constitutes are major factors that predispose children to suffer protein energy malnutrition in the community.

\section{Conclusion}

It was revealed during the study that ignorance, food taboo \& poor weaning of children by the mothers predispose their children to suffer protein energy malnutrition in Umuariam Community.

\section{Recommendations}

It is a statement of fact that the successful prevention of protein energy malnutrition among children will go a long way to promote healthy development. Based on the finding of this research, the researcher makes the following recommendations;

i. The public should as a matter of urgency be educated on the implications of protein energy malnutrition on child's growth and development, awareness programmes/campaigns on the need for proper selection of food by government/food agencies and all concerned. 
ii. More effort should be made on poverty alleviation, means of production of food can be made available and also mothers should be properly educated on the importance of exclusive breastfeeding, also an acceptable and affordable health service should be provided to the mothers and children.

iii. Another area is, government should provide equipment and facilities in our clinics, health centers, and hospital for more effective treatment of children with protein energy malnutrition.

\section{Acknowledgements}

None.

\section{Conflict of interest}

Author declares that there is no conflict of interest.

\section{References}

1. Black M. A Textbook of Medical Surgical Nursing. 6th ed. USA: W.B Saunder; 2004

2. United Nation International Children Emergency fund (UNICEF). Introduction to Malnutrition. 2012.

3. Victor CI. A Concise Text Medical Surgical Nursing. Revised Edition. Global Publishing Company; 2010.

4. Reuters. Breastfeeding could Save 1.3 million lives. 2009.

5. UNICEF. Progress for Children. A Report Card on Nutrition. 2007.

6. Shettigar D, Ansila M, George M, et al. Assessment of Knowledge of Mothers of Under five Children on Nutritional Problems: A Rural Community Based Study. National Journal of Community Medicine. 2013;4(1):141-144.

7. Ejaz MS and Latif N. Stunting and micronutrient deficiencies in malnourished children. J Pak Med Assoc. 2010;60(7):543-547.

8. Sudheer K. A Textbook of Nutrition. 11th ed. India: Florence Publishers; 2010.32p.

9. Alfred SP. A Textbook PM Infant Feeding. 4th ed. Oxford University Press; 2006.

10. Basavanthappa BT. Community health nursing. 2nd ed. New Delhi: Jaypee Brothers Medical Publishers; 2011. 135p.

11. Fostco JC and Bruce C. Measuring Socio-Economic Status in Health Research in Developing Countries. 2005.
12. Hussein AM, Adam D. Risk Factors of Protein Energy Malnutrition Deficiency among Children Under Five Years at Alruhal CampKass Locality South Darfur State 2012 Sudan. J Bacteriol Parasitol. $2015 ; 6: 252$.

13. Malafaia G. Protein-energy malnutrition as a risk factor for visceral leishmaniasis: a review. Journal of Parasite Immunology. 2016;31(10):587-596.

14. Sonia S and Malarvizhi M. Knowledge Regarding Protein Energy Malnutrition Among Mothers of Under Five Children Admitted in A Selected Hospital at Mangalore with A View to Provide Health Education. International Journal of Scientific Research. 2015;4(6):184-186.

15. Yadav S. Knowledge and Practices regarding Prevention of Protein Energy Malnutrition among Mothers of under Five Children. Asian Journal of Nursing Education and Research. 2016;6(1):96-100.

16. Dinesh KS. A Study to Evaluate the Effectiveness of Structured Teaching Programme on Knowledge of Mothers Regarding Protein Energy Malnutrition [PEM] and it's Home Based Diet Management Among Their Pre School Children in Selected Rural Areas at Gulbarga; 2011.

17. Ighogboja SI. Some factors contributing to protein-energy malnutrition in the middle belt of Nigeria. East Afr Med J. 1992;69(10):566-571.

18. ] Ubesie AC, Ibeziako NS, Ndiokwelu CI, et al. Under-five protein energy malnutrition admitted at the University of Nigeria Teaching Hospital, Enugu: a 10 year retrospective review. Nutrition Journal. 2012;11:43.

19. Cartmell E, Natalal H, Francois I, et al. Nutritional and Clinical Status of Children Admitted to the Malnutrition Ward, Maputo Central Hospital: A Comparison of Data from 2001 and 1983. J Trop Pediatr. 2005;51(2):102-105.

20. Omolbanin MR, Mitra M, Nahid M. Analyzing the level of knowledge and attitude of the mothers referring the urban health centers of Birjand about nutritional behaviors. J Edu Health Promot. 2014;3(37).

21. Nahar B, Ahmed T, Brown KH, et al. Risk Factors Associated with Severe Underweight among Young Children Reporting to a Diarrhoea Treatment Facility in Bangladesh. $J$ health Popul Nutr. 2010;28(5):476-483.

22. Faruque ASG, Ahmed AMS, Ahmed T, et al. Nutrition: Basis for Healthy Children and Mothers in Bangladesh. J Health Popul Nutr. 2008;26(3):325-339. 